\title{
Rancang Bangun Sistem Presensi Online dengan RFID Berbasis Internet Of Things (IoT) di Universitas Nahdlatul Ulama Blitar
}

\author{
${ }^{1}$ Fatra Nonggala Putra, ${ }^{2}$ Peni Nohantiya, ${ }^{3}$ Yuniar Alam \\ ${ }^{1}$ Program Studi Ilmu Komputer, Universitas Nahdlatul Ulama Blitar, \\ ${ }^{2}$ Program Studi Pendidikan Olahraga, Universitas Nahdlatul Ulama Blitar, \\ ${ }^{1}$ Program Studi Fisika, Universitas Nahdlatul Ulama Blitar, \\ Blitar, Indonesia
}

Email: ${ }^{1}$ fatranp@unublitar.ac.id

\begin{tabular}{l}
\hline Tersedia Online di \\
\hline http://www.jurnal.unublitar.ac.id/i \\
ndex.php/briliant
\end{tabular}

\begin{tabular}{l}
\hline Sejarah Artikel \\
\hline Diterima pada 9 Desember 2020 \\
Disetujui pada 20 Februari 2021 \\
Dipublikasikan pada 28 Februari \\
2021 \\
Hal. 216-224
\end{tabular}

Kata Kunci:

Presensi Online, RFID, Internet of Things, NodeMCU

DOI:

http://dx.doi.org/10.28926/briliant. v3i4.603

\begin{abstract}
Abstrak: Perekaman kehadiran bagi dosen dan mahasiswa dalam perkuliahan tatap muka merupakan hal yang penting. Selama ini proses pencatatan kehadiran bagi dosen dan mahasiswa di UNU Blitar masih manual yang ditulis pada jurnal perkuliahan. Dengan perkembangan dunia teknologi saat ini, hal tersebut dirasa tidak efektif. Selain membuang waktu selama proses pembelajaran, juga membuang waktu dalam proses perekapan dan monitoring keterlaksanaan perkuliahan. Disisi lain, wabah covid-19 yang melanda di negeri ini membuat setiap orang menjaga jarak termasuk dilarang bersentuhan secara langsung maupun kontak dengan benda yang pernah disentuh oarng lain. Oleh karena itu, pada penelitian ini dikembangkan sistem presensi online dengan RFID berbasis IoT yang mampu melakukan perekaman kehadiran dosen dan mahasiswa secara nirkontak dan realtime tercatat ke dalam sistem database. Pengguna dapat melihat secara langsung rekap kehadiran perkuliahan melalui Aplikasi Web dan Admin dapat memantau dan merekap keterlaksanaan perkuliahan secara online. Berdasarkan hasil pengujian blackbox menunjukkan bahwa sistem secara keseluruhan dapat berjalan dengan baik.
\end{abstract}

\section{PENDAHULUAN}

Busi Pesatnya perkembangan teknologi saat ini telah mempermudah kegiatan manusia dalam melakukan aktifitas kesehariannya. Salah satu aktifitas yang dipermudah dengan adanya teknologi adalah presensi kehadiran dengan hadirnya mesin fingerprint. Mesin fingerprint berfungsi merekam kehadiran seseorang berdasarkan sidik jari yang telah didaftarkan pada mesin. Menurut (Haq, 2016) Seiring dengan perkembangan ilmu pengetahuan dan teknologi, banyak teknologi yang dapat digunakan untuk mengurangi dan juga mengatasi permasalahan seputar disiplin kehadiran tepat waktu.

Perguruan tinggi merupakan lembaga pendidikan formal yang selalu rutin melakukan perekaman jejak untuk seluruh tenaga kependidikan, dosen dan mahasiswa dengan menggunakan presensi. Presensi merupakan hal utama untuk melihat perkembangan tingkat kedisiplinan seorang dosen dan mahasiswa. Sistem kehadiran yang dilaksanakan di UNU Blitar masih menggunakan sistem manual, yakni presensi menggunakan tanda tangan maupun pengecekan secara individu 
dengan memanggil nama masing-masing mahasiswa sehingga memakan waktu cukup lama dan juga berpotensi untuk terjadinya kecurangan atau manipulasi kehadiran. Kecurangan yang mungkin terjadi adalah titip absen dan absen setelah perkuliahan berakhir. Namun, Pada tahun ini merupakan masa yang berat bagi masyarakat dunia tidak terkecuali indonesia dengan adanya wabah Covid-19. Adanya Covid-19 mewajibkan setiap orang untuk menjaga jarak sehingga diwajibkan untuk menghindari kontak dengan orang secara langsung maupun benda yang digunakan orang lain tidak terkecuali kertas jurnal perkuliahan dan mesin fingerprint (Djalante et al., 2020).

Salah satu teknologi yang diperlukan untuk mengatasi permasalahan di atas adalah dengan menggunakan konsep internet of things (IoT) dengan memanfaatkan teknologi RFID. Perkembangan teknologi terutama dalam konsep Internet of Things (IoT) sangat populer dengan ditandai maraknya penggunaan istilah tersebut dalam berbagai artikel ilmiah (Espada, Yager, \& Guo, 2014). Konsep IoT dapat menjadi solusi meminimalisir kegiatan kontak dengan orang lain secara langsung maupun tidak langsung atau dengan kata lain nirkontak termasuk dalam proses presensi perkuliahan tatap muka.

Beberapa penelitian terkait presensi RFID berbasis IoT telah dilakukan oleh berbagai peneliti antara lain; (Al-barhamtoshy, Altalhi, \& Mashat, 2014) tentang sistem manajemen kehadiran bagi mahasiswa di lingkungan Universitas King Abdulaziz. Sistem tersebut dibangun dengan menggunakan bahasa pemrograman $\mathrm{C \#}$ dan database untuk menyimpan data kehadiran menggunakan SQL. Serupa dengan itu, (Alief, 2014) menggunakan RFID untuk prototype kelas pintar yang dalam lingkup kecil dengan menghubungkan RFID reader dengan komputer melalui kabel TCP. Sedangkan (Wiyanto, Handojo, 2019) memanfaatkan mikrokontroler arduino dan RFID untuk presensi online pekuliahan. Penggunaan teknologi RFID memiliki keunggulan untuk mempermudah proses presensi karena perekaman kehadiran cukup dengan menempelkan kartu pada alat pemindai (RFID Reader) dan secara otomatis identitas pengguna kartu akan akan tersimpan di dalam database sesuai jadwal.

Berdasarkan permasalahan dan penelitian relevan yang telah dijelaskan di atas, maka pada penelitian ini dirancang Sistem Presensi Online dengan RFID berbasis Internet Of Things (IoT). Penggunaan kartu RFID sebagai identitas bagi setiap dosen dan mahasiswa diharapkan dapat menghindarkan dari kontak langsung selama proses presensi. Selain itu, teknologi IoT bertugas mengatasi permasalahan potensi kecurangan dan manipulasi data serta memberi kemudahan dalam pengecekan kehadiran dan proses monitoring keterlaksanaan perkuliahan di UNU Blitar.

\section{METODE}

Bab ini menjelaskan metode yang digunakan untuk menyelesaikan permasalahan yang telah dipaparkan di atas. Ada 5 tahapan penelitian yang disusun dalam penelitian ini agar berjalan tersistematis seperti ditunjukkan pada Gambar 1. 


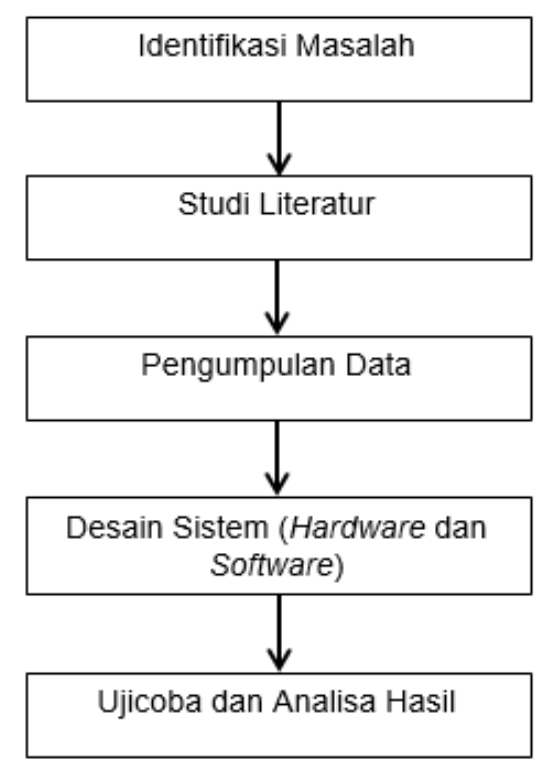

Gambar 1. Diagram Blok Alur Tahapan Penelitian

Tahapan tersebut antara lain yaitu; 1) Identifikasi Masalah, 2) Studi Literatur, 3) Pengumpulan Data, 4) Desain Sistem, dan 5) Uji coba dan Analisa Hasil. Penjelasan dari tahapan tersebut dijelaskan sebagai berikut:

\section{Identifikasi Masalah}

Presensi atau perekaman kehadiran dosen dan mahasiswa dalam kegiatan perkuliahan untuk setiap matakuliah masih dilakukan secara manual yaitu ditulis dalam jurnal perkuliahan. Ada 5 masalah utama yang akan diselesaikan dalam penelitian ini, yaitu:

1. Presensi manual membuang waktu di kelas. Waktu yang seharusnya untuk kegiatan pembelajaran harus berkurang karena digunakan untuk proses presensi.

2. Presensi manual berpotensi untuk terjadinya tindak kecurangan seperti tindakan titip absen maupun absen setelah perkuliahan berakhir.

3. Rekapitulasi kehadiran mahasiswa secara manual untuk tiap-tiap matakuliah memerlukan waktu yang cukup lama. Rekapitulasi kehadiran diperlukan guna mengetahui mahasiswa yang jumlah kehadirannya di bawah $75 \%$ sehingga berakibat tidak bisa mengikuti UAS.

4. Monitoring dan Rekapitulasi jumlah pelaksanaan perkuliahan yang telah dilaksankan oleh dosen di setiap matakuliah sulit untuk dipantau.

5. Pada masa pandemi Covid-19 diperlukan teknologi sistem presensi nirkontak yang efektif dan efisien.

\section{Studi Literatur}

Pada tahap ini dilakukan dengan mengkaji berbagai literatur yang berkaitan dengan topik penelitian presensi online khususnya yang menggunakan RFID berbasis IoT untuk identitas pengguna. Pada penelitian ini menggunakan referensi dari berbagai 
sumber seperti jurnal, konferensi, dan Website resmi dari peangkat keras yang digunakan dalam penelitian ini.

\section{Pengumpulan Data}

Dalam penelitian ini diperlukan berbagai data terkait perkuliahan yaitu; 1) Daftar Dosen, 2) Daftar Mahasiswa, 3) Jadwal Perkuliahan, 4) Jurnal Perkuliahan, dan 5) Daftar Ruang Perkuliahan. Semua data tersebut diperoleh langsung dari Administrator yang bertanggungjawab di UNU Blitar.

\section{Desain Sistem}

Tahapan desain sistem dibagi menjadi 3 (tiga) yaitu; 1) Perancangan Perangkat Keras (Hardware), 2) Perancangan Perangkat Lunak (Software), dan 3) Integrasi Perangkat Keras dan Perangkat Lunak.

\section{Perancangan Perangkat Keras (Hardware)}

Komponen yang diperlukan untuk merancang hardware dari sistem presensi online RFID antara lain: 1) NodeMCU, RFID Reader (MFRC-522), LCD 20x4, I2C, dan Buzzer. Desain rangkaian alat (hardware) yang dirancang untuk membuat presensi online RFID berbasis IoT ditunjukkan pada Gambar 2.

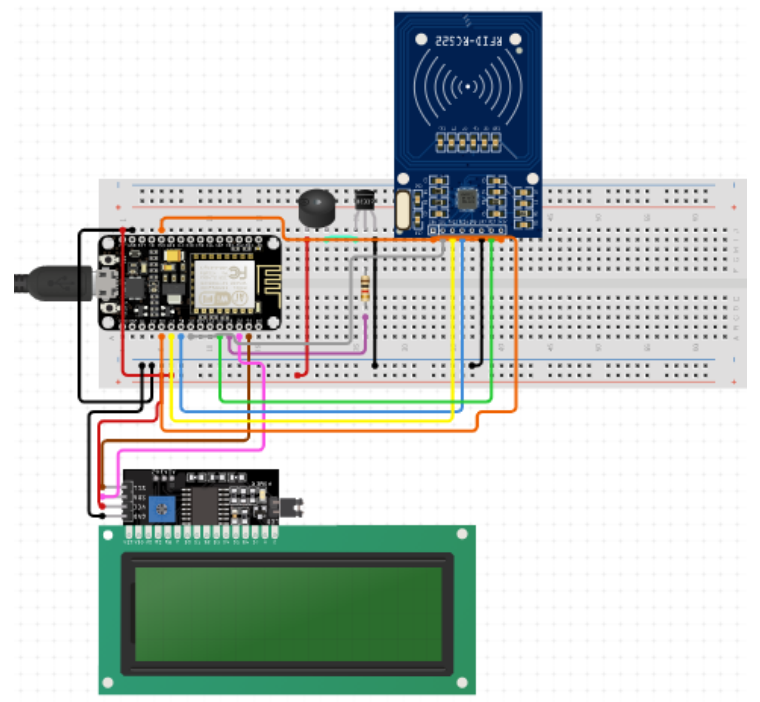

Gambar 2. Desain Rangkaian Alat Presensi Online RFID

\section{Perancangan Perangkat Lunak (Software)}

Untuk mendukung kinerja hardware guna mencapai tujuan penelitian, perlu dirancang aplikasi pendukung kinerja sistem yang dibangun menggunakan framework php yaitu Codeigniter. Ada 3 (tiga) tipe pengguna yang ditetapkan dalam aplikasi ini, yaitu: 1) Admin, 2) Dosen, dan 3) Mahasiswa. Masing-masing pengguna mempunyai antarmuka yang berbeda dan fitur yang berbeda sesuai dengan kebutuhan dan tugasnya. 


\section{Integrasi Perangkat Keras dan Perangkat Lunak}

Konsep dari teknologi IoT adalah keterhubungan benda dengan internet sehingga dapat dilakukan monitoring dan kontrol secara realtime atau paling tidak near-realtime. Benda-benda yang dimaksud dalam sistem ini adalah kartu dan perangkat keras pemindainya. Arsitektur sistem presensi online dengan RFID berbasis IoT ditunjukkan pada Gambar 3.

Perangkat keras pemindai kartu yang dirancang memiliki 2 (dua) mode yaitu mode Add dan mode Reader. Mode add digunakan untuk memindai kartu untuk mendaftarkan kartu baru ke dalam database. Sedangkan mode Reader berfungsi sesuai tugas utama sistem presensi online ini yaitu mencatat kehadiran dosen dan mahasiswa pada perkuliahan tatap muka. Diagram alir sistem sebagai mode $A d d$ ditunjukkan pada Gambar 4. Sedangkan diagram alir sistem sebagai mode Reader ditunjukkan pada Gambar 5.

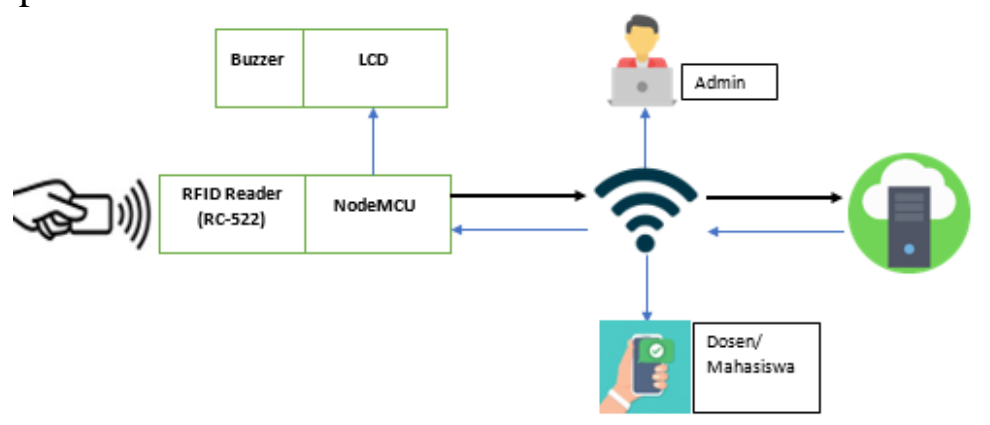

Gambar 3. Arsitektur Sistem Presensi Online RFID

\section{Ujicoba dan Analisa Hasil}

Setelah tahap desain sistem, pada tahap ini akan difokuskan pada pengujian untuk melihat aspek fundamental dari kinerja sistem tanpa harus mengetahui detail kinerja internal sistem dengan menggunakan teknik pengujian blackbox (Mohd. Ehmer \& Farmeena, 2012). Pada pengujian ini jika terdapat kesalahan pada bagian tertentu, maka akan segera diperbaiki dan dapat diuji ulang. 


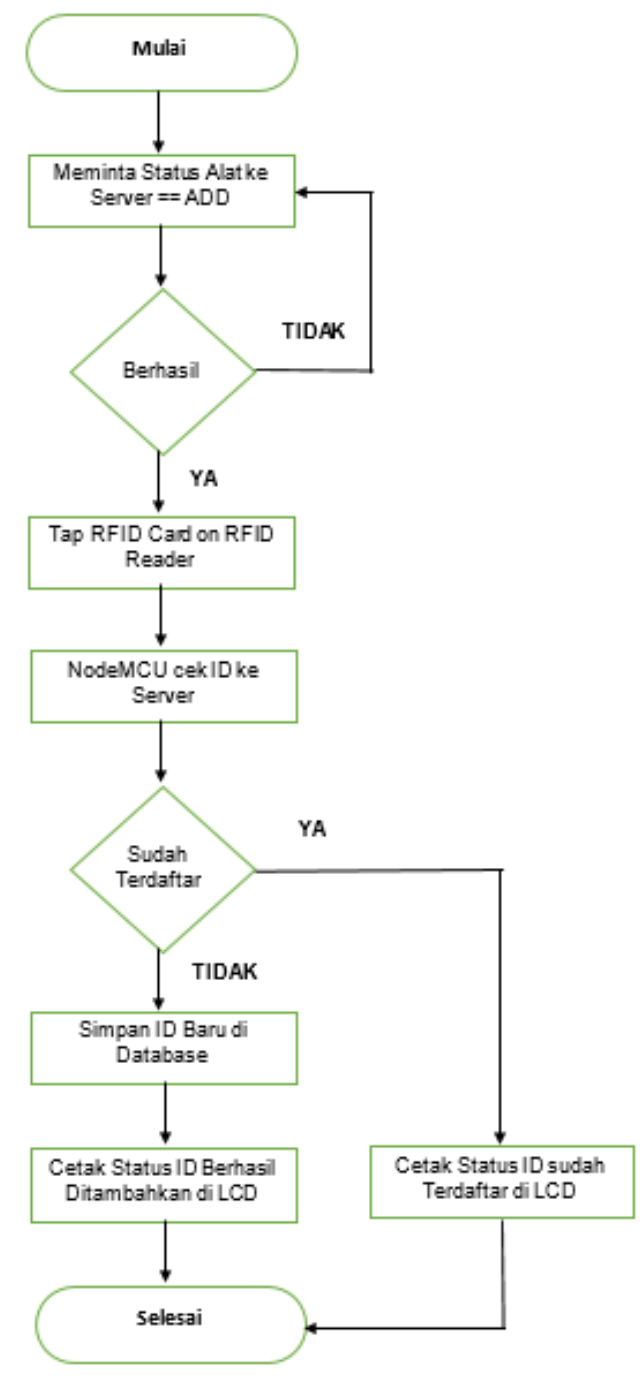

Gambar 4. Diagram Alir Mode Add

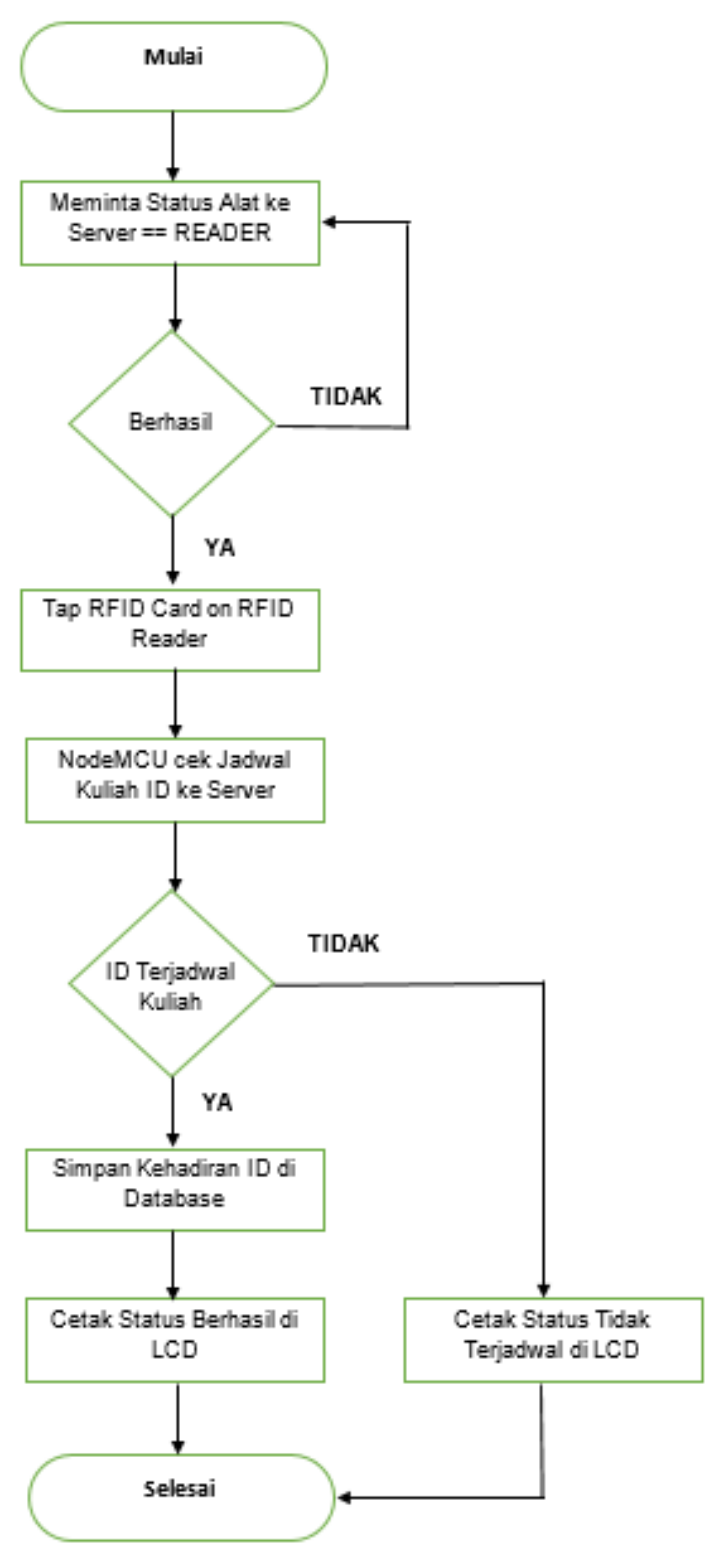

Gambar 5. Diagram Alir Reader

\section{HASIL DAN PEMBAHASAN}

Hasil dari penelitian ini berupa sistem presensi online yang mengintegrasikan antara perangkat keras dan perangkat lunak. Perangkat keras bekerja sebagai pembaca kartu identitas dari dosen dan mahasiswa. Sistem perangkat keras dapat bekerja dengan baik dalam membaca kartu rfid identitas pengguna dan mengirimkan data ke server.

Dari asspek perangkat lunak, halaman utama dari aplikasi web presensi online berupa form login bagi setiap user untuk dapat mengakses laman mereka masing-masing. Tampilan halaman utama ditunjukkan pada Gambar 6. Setelah 
behasil login, berikutnya akan masuk ke halaman halaman dashboard. Untuk halaman dashboard admin ditunjukkan pada Gambar 7. Sedangkan halaman dashboard dosen/mahasiswa ditunjukkan pada Gambar 8. Pada Gambar 9 menunjukkan tampilan jika dosen/mahasiswa telah berhasil melakukan presensi sesuai jadwal yang ada.

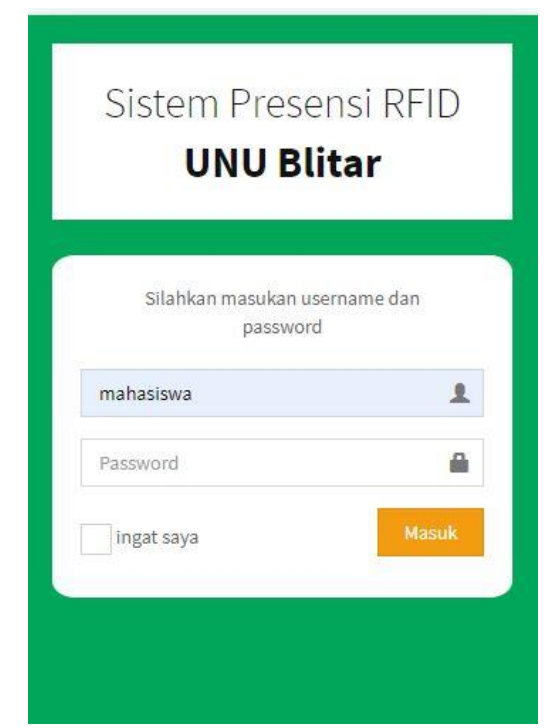

Gambar 6. Halaman Utama Aplikasi Presensi Online RFID
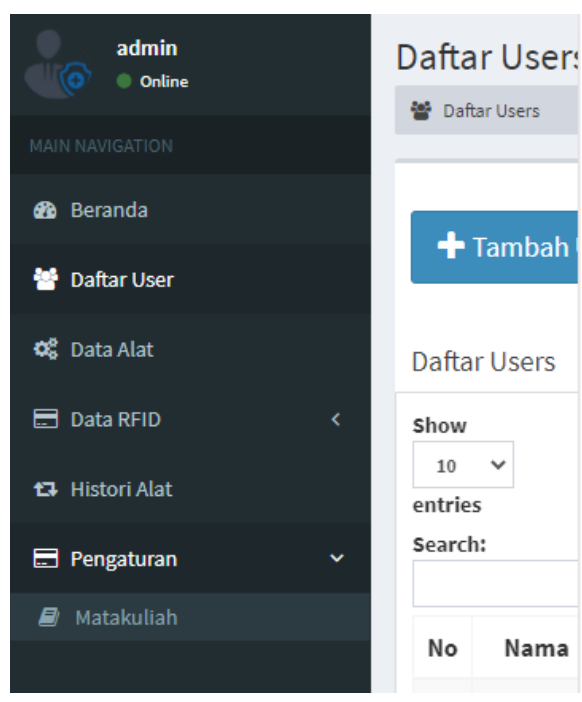

Gambar 7. Halaman Dashboard Admin

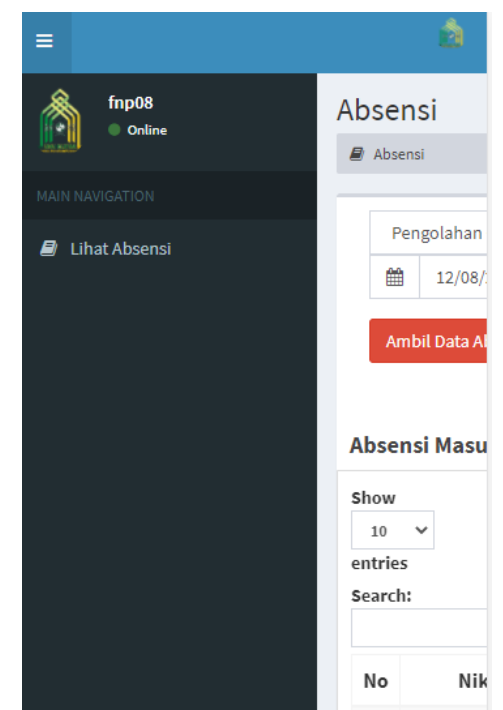

Gambar 8. Halaman Dashboard Dosen/Mahasiwa

Ujiba kinerja sistem dengan teknik uji blackbox dilakukan sesuai skenario pada Tabel 1. Dari hasil ujicoba tersebut dapat disimpulkan bahwa secara keseluruhan sistem dapat bekerja dengan baik. 


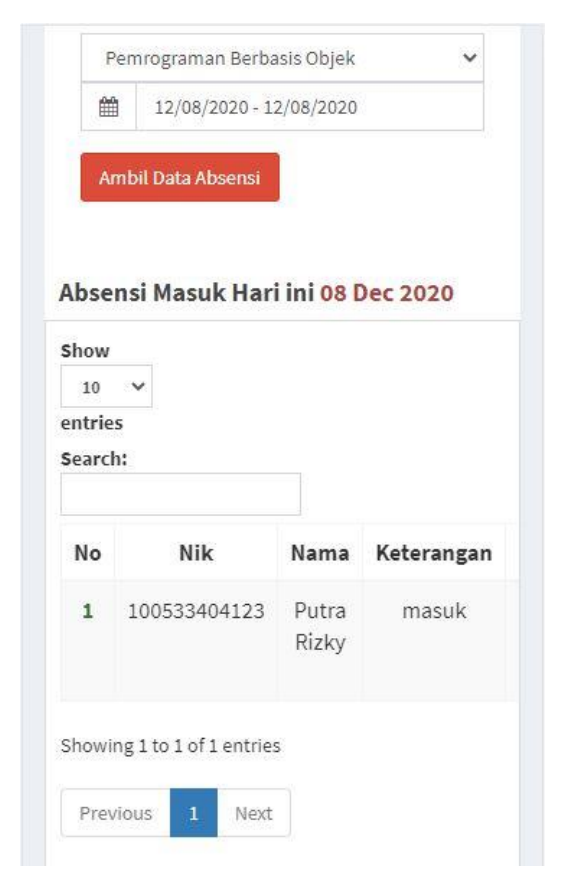

Gambar 9. Tampilan Rekap Presensi yang Telah Berhasil

Tabel 1. Skenario Pengujian Blackbox

\begin{tabular}{|c|c|c|c|}
\hline Masukan & Fungsi & Luaran & Hasil \\
\hline Akses Laman Presensi & Membuka laman login & $\begin{array}{l}\text { Menampilkan laman } \\
\text { login }\end{array}$ & Accepted \\
\hline $\begin{array}{l}\text { Ketik Username dan } \\
\text { Password }\end{array}$ & $\begin{array}{l}\text { Mengisi user dan } \\
\text { password }\end{array}$ & Menampilkan sesuai isian & Accepted \\
\hline Klik tombol login & $\begin{array}{l}\text { Membuka halaman } \\
\text { dashboard sesuai role } \\
\text { (admin/dosen/mahasiswa) }\end{array}$ & $\begin{array}{l}\text { Menampilkan halaman } \\
\text { dashboard sesuai role } \\
\text { (admin/dosen/mahasiswa) }\end{array}$ & Accepted \\
\hline $\begin{array}{l}\text { Klik daftar user } \\
\text { (halaman admin) }\end{array}$ & $\begin{array}{l}\text { Membuka halaman } \\
\text { daftar user }\end{array}$ & $\begin{array}{l}\text { Menampilkan halaman } \\
\text { daftar user }\end{array}$ & Accepted \\
\hline $\begin{array}{l}\text { Klik tambah user } \\
\text { (halaman admin) }\end{array}$ & $\begin{array}{l}\text { Membuka halaman } \\
\text { tambah user }\end{array}$ & $\begin{array}{l}\text { Menampilkan halaman } \\
\text { tambah user }\end{array}$ & Accepted \\
\hline $\begin{array}{l}\text { Klik data alat } \\
\text { (halaman admin) }\end{array}$ & $\begin{array}{l}\text { Membuka halaman } \\
\text { data alat presensi }\end{array}$ & $\begin{array}{l}\text { Menampilkan halaman } \\
\text { data alat presensi }\end{array}$ & Accepted \\
\hline $\begin{array}{l}\text { Klik data rfid } \\
\text { (halaman admin) }\end{array}$ & $\begin{array}{l}\text { Membuka halaman daftar } \\
\text { rfid }\end{array}$ & $\begin{array}{l}\text { Menampilkan halaman } \\
\text { daftar rfid }\end{array}$ & Accepted \\
\hline $\begin{array}{l}\text { Klik matakuliah } \\
\text { (halaman admin) }\end{array}$ & $\begin{array}{l}\text { Membuka halaman } \\
\text { jadwal matakuliah }\end{array}$ & $\begin{array}{l}\text { Menampilkan halaman } \\
\text { jadwal matakuliah }\end{array}$ & Accepted \\
\hline $\begin{array}{l}\text { Klik lihat absensi } \\
\text { (halaman } \\
\text { admin/dosen/mahasiswa) }\end{array}$ & $\begin{array}{l}\text { Melihat dan download } \\
\text { rekap presensi }\end{array}$ & $\begin{array}{l}\text { Melihat dan download } \\
\text { rekap presensi }\end{array}$ & Accepted \\
\hline $\begin{array}{l}\text { Klik logout } \\
\text { (halaman } \\
\text { admin/dosen/mahasiswa) }\end{array}$ & $\begin{array}{l}\text { Keluar dari halaman } \\
\text { admin/dosen/mahasiswa }\end{array}$ & $\begin{array}{l}\text { Kembali ke laman depan } \\
\text { (form login) }\end{array}$ & Accepted \\
\hline
\end{tabular}




\section{KESIMPULAN}

Sistem yang telah dibuat mempunyai 3 (tiga) role pengguna yaitu user Admin, user Dosen, dan user Mahasiswa. Masing-masing user mempunyai interface yang berbeda dan fitur yang berbeda. Setelah melalui tahap penelitian dapat disimpulkan bahwa sistem secara keseluruhan dapat bekerja dengan baik. Beberapa masalah yang telah dianalisa diawal dapat diatasi dengan adanya sistem presensi online dengan rfid berbasis IoT ini, seperti ; proses presensi tidak menggangu aktifitas inti perkuliahan, mengurangi terjadinya kecurangan konvesional, rekapitulasi dan monitoring kehadiran dosen dan mahasiswa mudah dilakukan, dan yang terakhir ditengah wabah covid-19, sistem ini menjadi salah satu upaya meminimalisir penyebaran covid-19 dengan melakukan presensi secara nirkontak.

\section{SARAN}

Pada penelitian selanjutnya bisa ditambahkan kamera untuk mengambil gambar pengguna yang sedang melakukan presensi. Hal ini diharapkan bisa menjadi salah satu solusi mengatasi kecurangan jika ada mahasiswa yang melakukan presensi menggunakan Kartu RFID mahasiswa lain (titip absen).

\section{DAFTAR RUJUKAN}

Al-barhamtoshy, H. M., Altalhi, A. H., \& Mashat, A. S. (2014). Automation of Attendances in Classrooms using RFID, 5(2), 502-509.

Alief, R. (2014). PEMANFAATAN TEKNOLOGI RFID MELALUI KARTU IDENTITAS DOSEN PADA PROTOTIPE SISTEM RUANG KELAS CERDAS. Transmisi, 6, 62-68.

Djalante, R., Nurhidayah, L., Van Minh, H., Phuong, N. T. N., Mahendradhata, Y., Trias, A., ... Miller, M. A. (2020). COVID-19 and the ASEAN responses: Comparison and analysis through policy science. Progress in Disaster Science, 8, 100129. https://doi.org/10.1016/j.pdisas.2020.100129

Espada, J. P., Yager, R. R., \& Guo, B. (2014). Internet of things: Smart things network and communication. Journal of Network and Computer Applications, 42, 118-119. https://doi.org/10.1016/j.jnca.2014.03.003

Haq, M. S. (2016). PENGEMBANAGAN APLIKASI PRESENSI PEGAWAI BERBASIS FINGERPRINT. Jurnal Dinamika Manajemen Pendidikan, 1(1), 34-40.

Mohd. Ehmer, K., \& Farmeena, K. (2012). A Comparative Study of White Box , Black Box and Grey Box Testing Techniques. International Journal of Advanced Computer Science and Applications, 3(6), 12-15.

Wiyanto, E. P., Handojo, A., Lim, R., \& Surabaya, J. S. (2019). Sistem Presensi Perkuliahan pada Universitas Kristen Petra Berbasis RFID Dan Arduino. Jurnal Infra Petra, 3-7. 